\title{
Adam Puławski, W obliczu zagłady. Rząd RP na Uchodźstwie, Delegatura Rzadu RP na Kraj, ZWZ-AK wobec deportacji Żydów do obozów zagłady (1941-1942), Lublin: Instytut Pamięci Narodowej, Oddział w Lublinie, 2009, 583 s.
}

Badania nad tym, co na temat nazistowskich planów zgładzenia Żydów europejskich wiedziały rządy głównych aliantów zachodnich - Wielkiej Brytanii i Stanów Zjednoczonych - w momencie wcielania ich w życie, rozpoczęli pod koniec lat sześćdziesiątych historycy pochodzący głównie z krajów anglojęzycznych, choć także z Izraela. Próbowali oni ustalić, kiedy dokładnie alianci dowiedzieli się o tych planach, skąd i jakie decyzje podjęli po uzyskaniu tych informacji. Owe badania, co oczywiste, doprowadziły historyków do Polski, gdyż, jak to ujął jeden z najwybitniejszych wspomnianych badaczy, „pierwsze prawdziwe, szczegółowe informacje o «ostatecznym rozwiązaniu» pochodziły właśnie" stamtąd"

W połowie lat osiemdziesiątych istniały już prace badawcze oparte na polskich źródłach, w których postawiono podobne pytania w odniesieniu do polskiego podziemia i Rządu Rzeczypospolitej Polskiej na Uchodźstwie. Autorom tych książek pracę utrudniał jednak brak dostępu do najważniejszych archiwów w Polsce, z których większość była zamknięta nie tylko dla zagranicznych naukowców, lecz także dla polskich historyków. Oznaczało to, że ich dzieła odzwierciedlały jedynie treść niepełnych, choć obszernych, zasobów archiwów zagranicznych - Instytutu Polskiego [i Muzeum im. gen. Władysława Sikorskiego] oraz Studium Polski Podziemnej w Londynie, Yad Vashem w Jerozolimie i Instytutu Hoovera w Stanford w Kalifornii (Hoover Institution on War, Revolution, and Peace). Nawet polscy badacze, którzy włączyli się w tę dyskusję w pierwszych latach po obaleniu reżimu komunistycznego, nie mogli w pełni korzystać $\mathrm{z}$ rodzimych archiwów i w głównej mierze musieli się opierać na materiałach znajdujących się poza granicami kraju.

Dzisiaj sytuacja wygląda zgoła inaczej, co dobitnie poświadcza wnikliwe i szczegółowe studium Adama Puławskiego odtwarzające przepływ informacji dotyczących mordów na ludności żydowskiej w Polsce, począwszy od źródeł, z których napływały, po ich przekazywanie rządowi na uchodźstwie w okresie od czerwca 1941 do czerwca 1942 r. Puławski dotarł do niedawno udostępnionych materiałów, które pozostawały poza zasięgiem jego poprzedników, w tym do zbiorów zarówno krajowych, jak i terenowych struktur Armii Krajowej, akt Delegatury Rządu RP na Kraj, a także archiwaliów zgromadzonych w Instytucie Pamięci Narodowej. Zapoznanie się z tą dokumentacją umożliwiło mu precyzyjną i, jak się wydaje, niemal

${ }^{1}$ Walter Laqueur, The Terrible Secret: Suppression of the Truth about Hitler's 'Final Solution', Boston: Little, Brown, 1980, s. 101. 
pełną rekonstrukcję danych o masowym mordowaniu Żydów w okupowanej Polsce (włącznie z ziemiami wcielonymi do Rzeszy, Generalnym Gubernatorstwem i Kresami). Od czasu pierwszych masowych rozstrzeliwań na froncie wschodnim, które nastapiły po ataku Niemiec na ZSRR w czerwcu 1941 r., aż do lata 1942 r. i wielkiej akcji deportacyjnej z getta warszawskiego dane te były zbierane przez organy cywilne oraz oddziały wojskowe polskiej konspiracji i przekazywane do Londynu. Dzięki wysiłkom Puławskiego naukowcy wreszcie mogą z dużą dozą prawdopodobieństwa odtworzyć drogę, jaką przeszła każda informacja, by dotrzeć do warszawskiego podziemia, poznać sposób, w jaki została doręczona, środki i kanały jej przekazania oraz ustalić, ile czasu upłynęło od odbioru danej informacji do jej rozpowszechnienia. Książka Puławskiego pozwala też porównać informacje zdobywane w okupowanej ojczyźnie z tymi, które docierały do Londynu, i ocenić, jak długo trwało przekazywanie raportów z polskiej do brytyjskiej stolicy. Publikacja ta wypełnia istotne luki informacyjne widoczne w poprzednich opracowaniach, a w niektórych przypadkach skłania nawet do skorygowania wcześniejszych poglądów na temat tego, w jaki sposób i kiedy dane dokumenty wysyłano bądź otrzymywano.

We wstępie do swej książki Puławski jasno stwierdza, że jednym z jego głównych zamiarów było zweryfikowanie dotychczasowej wiedzy: „Celem niniejszej pracy jest w pierwszej kolejności ustalenie [...] «prostych faktów» dotyczących czasu i sposobu zdobywania przez Związek Walki Zbrojnej-Armię Krajową, delegaturę i rząd polski informacji o masowych mordach na ludności żydowskiej” (s. 11-12). Autor porusza ponadto wiele problemów interpretacyjnych, stanowiących przed laty przedmiot sporów naukowców, w nadziei na to, że przedstawiona przezeń faktografia zawęzi krąg kwestii spornych:

[J]ak rozumiano te informacje i kiedy uświadomiono sobie, że jest to zorganizowana i totalna akcja zagłady ludności żydowskiej[?] [...] [C]zy przesłanie danej informacji do Londynu wynikało z przyjętych procedur, czy była to wysyłka „celowa”, np. w charakterze specjalnego raportu lub depeszy, czy przesyłanie informacji było świadomą metodą przeciwstawienia się mordom[?] [...] [C]zy władze podziemne i emigracyjne dopuszczały inną formę reakcji, np. oddziaływanie na postawy i postępowanie ludności polskiej, moralne wspieranie ofiar, a nawet podjęcie czynnej akcji[?] [...] [Jakie] uwarunkowa[nia] [...] miały wpływ na podejmowanie decyzji, np. pogląd[y] na tzw. kwestię żydowską członków ZWZ-AK, pracowników delegatury i pośrednio działaczy partii politycznych oraz członków rządu i Rady Narodowej[?] (s. 12).

Puławski udziela na te pytania odpowiedzi na podstawie starannie przeprowadzonej i wyważonej analizy licznych źródeł oraz znajomości szerszego kontekstu w następujący sposób: Do przywódców struktur cywilnych i oddziałów wojskowych polskiego podziemia prawda o tym, że Żydom polskim grozi systematyczna i całkowita zagłada z rąk Niemców, docierała od października 1941 r., kiedy to po raz pierwszy otrzymali oni wiarygodne raporty o masowych rozstrzeliwaniach Żydów na Litwie, aż do kwietnia 1942 r., gdy zaczęli otwarcie mówić o „planie wytracania” 
Żydów w Generalnym Gubernatorstwie. W tym czasie praktycznie wszystkie informacje o masowych zabójstwach Żydów zgromadzone przez warszawskie podziemie przesyłano do rządu polskiego w Londynie. Raporty w sprawie Żydów często oznaczano jako szczególnie ważne i wysyłano jak najszybciej. Zarówno polscy, jak i żydowscy przywódcy podziemia popierali taką procedurę w przekonaniu, iż samo ujawnienie prawdy o mordowaniu Żydów sprawi, że Niemcy ograniczą ten proceder. Tymczasem $w$ momencie gdy raporty o likwidacji gett na Lubelszczyźnie i gazowaniu ludzi w Chełmnie i Bełżcu (wiosną 1942 r.) powinny były im uświadomić, że samo nagłaśnianie sprawy nie daje oczekiwanego efektu, podziemie skierowało swoją uwagę na coraz bardziej zagrażający Polakom terror ze strony Niemców, nasilony po nieudanej próbie wyłonienia kolaboracyjnego rządu polskiego. Informacje przekazywane do Londynu i publikacje w podziemnej prasie o antypolskich represjach znacząco przeważały nad tymi poświęconymi losowi zgotowanemu wydanym na śmierć Żydom (choć AK uwzględniała kwestię żydowską w większym stopniu niż delegatura). Co więcej, podczas gdy relacjom na temat niebezpieczeństw czyhających na Polaków towarzyszyły zwykle prośby o odwet ze strony Zachodu, raporty o Żydach miały charakter czysto informacyjny. W rzeczywistości bowiem w kwietniu 1942 r. środowiska podziemne były przekonane, że skazanie polskich Żydów na zagładę zwiastuje podobny los Polaków.

W tym samym czasie, między październikiem 1941 a kwietniem 1942 r., większość informacji o mordowaniu Żydów, które docierały do Polski, krążyła w środowisku rządowym, lecz nie była upubliczniana. Rządowe publikacje przedstawiały sytuację Żydów w Polsce z perspektywy życia w getcie, zamiast uświadamiać o śmiertelnym niebezpieczeństwie, które im bezpośrednio zagrażało. „Wydaje się, że był to wynik świadomej decyzji władz polskich”, które obawiały się, że „pisanie o masowych mordach na ludności żydowskiej na Wschodzie zniweczyłoby" polskie wysiłki, by skłonić Wielką Brytanię i Stany Zjednoczone do zobowiązania się, że po wojnie wymierzą Niemcom karę za zbrodnie przeciwko narodowi polskiemu (s. 553-554). „Na wiosnę 1942 r. [...] prowadzono [...] kampanię propagandową, w której pokazywano [...] Polskę jako kraj, który z racji [...] coraz cięższych prześladowań zasługuje na wyjątkowe traktowanie [...]. Masowe mordy na ludności żydowskiej nie pasowały do tego obrazu" (s. 554). Stanowisko rządu zmieniło się dopiero pod koniec maja, kiedy uznano, że tylko informacje o mordowaniu Żydów przedstawione na ogólnym tle polskiej niedoli mogą przełamać powściągliwość rządów Wielkiej Brytanii i Stanów Zjednoczonych w kwestii oczekiwanego przez Polaków zobowiązania. Wrażenie to spotęgowała niemiecka akcja odwetowa w czeskiej wsi Lidice w czerwcu 1942 r., po której polscy przywódcy zaczęli się obawiać, że Polska straci „status państwa najbardziej pokrzywdzonego”: „[t]ylko pokazanie, że w Polsce rzeczywiście dzieją się zbrodnie większe niż w Lidicach, pozwalało odzyskać zainteresowanie światowej opinii publicznej" (s. 555). Nawet jednak po podjęciu tej decyzji rząd napotkał opór ze strony prawicowych partii w Radzie Narodowej. Ich przedstawiciele właśnie wtedy zainicjowali „debat[y], podczas których nie brakowało akcentów antysemickich” (s. 555). A zatem to względy 
praktyczne determinowały sposób, w jaki rząd w Londynie przedstawiał nieszczęsny los przeznaczony polskim Żydom. Poczucie moralności czy fakt, że trudno było uwierzyć, iż niewyobrażalna wizja unicestwienia trzech milionów polskich Żydów się ziści, również mogły mieć wpływ na reakcje niektórych polskich przywódców, lecz w ostatecznym rozrachunku to chłodny polityczny pragmatyzm kierował zarówno AK, delegaturą, jak i rządem polskim na uchodźstwie.

Czytelnicy, którzy zetknęli się z moimi publikacjami (zaliczam się do grona badaczy, którzy zajmowali się tą kwestią w latach osiemdziesiątych i korzystali tylko z dokumentów znajdujących się poza granicami Polski), nie będą zdziwieni, że zgadzam się z meritum tych konkluzji. Mimo iż mogę spierać się z Puławskim o pewne drobiazgi i niuanse (a on ze mna), w gruncie rzeczy jego ustalenia dotyczące postawy rządu na uchodźstwie w badanym okresie są zbieżne z tymi, które prezentowałem ówcześnie. Co więcej, Puławski doskonale rozumie, że te wnioski odnoszą się tylko do konkretnego okresu; jak zauważył w ostatnim zdaniu swej książki: „[k]olejne badania pozwolą wykazać, na ile o [braku] wspólnoty [obywatelskiej z Żydami] można mówić w odniesieniu do kolejnych lat drugiej wojny światowej, szczególnie w aspekcie występowania z wnioskami o odwet za eksterminację ludności żydowskiej” (s. 556). Istotnie, książka Puławskiego jest wolna od powszechnej tendencji do wysnuwania z badań historycznych odnoszących się do niewielkiej liczby epizodów uogólnionych wniosków o tym, w jaki sposób polskie (czy jakiekolwiek inne) społeczeństwo jako całość powinno być postrzegane przez siebie oraz przez innych. Wygląda na to, że Puławski zdaje sobie sprawę, iż napisał monografię o stosunkowo małej grupie Polaków, których postawy i działania „w obliczu zagłady” znacznie się od siebie różniły. Oby czytelnicy podchodzili do jego książki z podobną świadomością.

David Engel

Z języka angielskiego przełożyła Ewa Felska 